\title{
Developing Beef Cattle in Banyumas Regency: Potentials and Strategies
}

\author{
Nunung Noor Hidayat*, Krismiwati Muatip and Rahayu Widiyanti \\ Faculty of Animal Science, Jenderal Soedirman University, Purwokerto, Indonesia \\ *corresponding e-mail: nunungnoorhidayat@yahoo.com
}

\begin{abstract}
Optimum development of beef cattle is feasible in the potential area with effective strategies. This research was conducted in Banyumas regency. The purpose of this study was to describe the potential of Banyumas Regency in developing beef cattle farming as the basis for its development strategy. A survey method was conducted to obtain the secondary data supported by primary data subjected to simple descriptive statistical analysis consisting of mean values, distribution frequency, cross-tabulation and trend analysis. Ruminant potentials were investigated using LQ analysis, and developmental strategies were formulated using a SWOT analysis. The result showed a fluctuated but positive improvement trend of beef cattle population in Banyumas. Sub-districts potentially developed for beef cattle centres (LQ $>1$ ) included Kembaran, Sokaraja, Kalibagor, Kedungbanteng, Karanglewas, Sumbang and Baturraden. A quantitative SWOT matrix analysis showed that the internal factor was 0.0298 (X-axis), and the external factor was -0.2941 ( $Y$-axis). Conclusively, the key strategy to develop beef cattle in Banyumas was a differential strategy.
\end{abstract}

Keywords: beef cattle, potential, strategy, development, survey

Abstrak. Pengembangan sapi potong secara optimal dapat dilakukan di daerah potensial dengan strategi yang efektif. Penelitian ini dilakukan di Kabupaten Banyumas. Tujuan dari penelitian ini adalah untuk mendeskripsikan potensi Kabupaten Banyumas dalam pengembangan peternakan sapi potong sebagai dasar strategi pengembangannya. Metode survei dilakukan untuk memperoleh data sekunder yang didukung oleh data primer yang dilakukan analisis statistik deskriptif sederhana yang terdiri dari nilai mean, frekuensi distribusi, tabulasi silang dan analisis trend. Potensi ruminansia diselidiki menggunakan analisis $L Q$, dan strategi pengembangan dirumuskan menggunakan analisis SWOT. Hasil penelitian menunjukkan tren peningkatan populasi sapi potong di Banyumas berfluktuasi namun positif. Kecamatan yang berpotensi dikembangkan untuk sentra sapi potong (LQ> 1) meliputi Kembaran, Sokaraja, Kalibagor, Kedungbanteng, Karanglewas, Sumbang dan Baturraden. Analisis matrik SWOT kuantitatif menunjukkan bahwa faktor internal adalah 0,0298 (sumbu X), dan faktor eksternal adalah - 0,2941 (sumbu Y). Secara meyakinkan, strategi kunci pengembangan sapi potong di Banyumas adalah strategi diferensial.

Kata kunci: sapi potong, potensi, strategi, perkembangan, survei

\section{Introduction}

Beef cattle farming is vital for meat supply in Indonesia; beef comprises around 55 percent of domestic demand. Domestic meat demand increases along with the growing population, public income, and nutrition awareness. To date, cattle breeders only fulfil two-thirds of total domestic demand; therefore, to fill the gap, beef is imported from other countries, the biggest is from Australia. The Indonesian government is formulating strategies to improve production and population of beef cattle to reach the targeted self-sustained meat in 2026. One of the principal foci of accelerating livestock population is UPSUS SIWAB (Distinct Efforts of Compulsory Gestating Cattle). National data reported that UPSUS SIWAB had been a great success. Therefore, a follow-up breeding program should seek to optimize beef cattle productivity. An optimum beef cattle productivity is achievable given the optimum condition, including the environment. Accordingly, it is crucial to focus on developing an area that is comparatively superior in production, feed availability and market. One of the methods to determine the central area for beef cattle development is by calculating the Location Quotient (LQ) index. 
Hendarto (2000) stated that LQ analysis presents a relative comparison of capacity in one sector in particular area with that in other sectors or subsectors in a larger area.

Determining the LQ index is crucial to develop a commodity. When combined with LQ forage production, the indexes can optimize the development of beef cattle commodity. Upon gathering information on the basic potential of cattle commodity, the next step is creating a strategic plan to develop ruminant commodity. According to Santosa et al. (2013), LQ analysis is a statistical model that uses the characteristics of a sector to determine the specialization of a region, either basic or nonbasic sectors. Population concentration is the standard criteria for selecting the potential area of beef cattle development. Susanti et al. (2014) stated that the strategy to improve beef cattle contribution to the economics of Central Java is a regional planning approach.

A strategic plan is formulated using a SWOT analysis. Santosa et al. (2013) stated that SWOT analysis for developing livestock business includes internal environment analysis (strength and weakness) and external environment (opportunity and threat). After all contributing factors to sustainable livestock business are gathered, the next step was utilizing all factors in the qualitative model of strategy formulation. Fahmi (2011) argued that internal factors are related to the internal condition that provides strengths and weaknesses for development. External factors are the potential opportunities and threats. The purpose of this study was to describe the potential of Banyumas Regency in developing beef cattle farming as the basis for its development strategy.

\section{Materials and Methods}

This study used observation and survey methods, utilizing the secondary data as the primary source, supported by the primary data. The secondary data were obtained from several village administrative organizations (OPD): Bapelitbangda Banyumas, Banyumas Fishery and Livestock Agency, Statistics Bureau (BPS), Banyumas regency and all sub-districts in Banyumas. The primary data were generated from interviews with beef cattle farmers from three most-populated regions collected using a simple random sampling method of 60 respondents. It also accommodates the opinions of 15 experts.

\section{Data Analysis}

In achieving research objectives, a set of data analysis was conducted as follows:

a. To investigate the 6-year trend of beef cattle population in Banyumas, a simple regression analysis was undertaken and reported descriptively using an equation below:

$$
\begin{aligned}
Y i & =a+b X \\
Y i & =\text { Population; } X=n-Y e a r
\end{aligned}
$$

b. To investigate the potential development of beef cattle farming in Banyumas, an approach to the production aspect was conducted using a Location Quotients (LQ) analysis and spatial approach. Hartono (2012) mentioned that the LQ method could identify the prime commodity of a region. The equation is below:

Note :

$X_{i j}$ : beef cattle population $\mathrm{i}$ in sub-district $\mathrm{j}$

$\mathrm{Xi}$ : total population of ruminant in subdistrict $\mathrm{j}$

X.j : beef cattle population in Banyumas

$X$..: total population of ruminant in Banyumas

$L Q>1$ : It indicated a relative concentration of beef cattle activity in a sub-district compared to the total area, or beef cattle population was centralized in i sub-district. At this point, beef cattle play a crucial role in the area.

$\mathrm{LQ}<1$ : There is no concentration or centralization of beef cattle population in $\mathrm{i}$ sub-district 
c. To formulate a strategic plan to develop ruminant, a SWOT analysis was undertaken. SWOT analysis included strength, weakness, opportunity and threat to evaluate the external condition (industry) and internal condition (cattle breeding). An objective investigation into SWOT analysis would establish the foundation of strategy plan in developing prime ruminant breeding.

\section{Results}

\section{The Trend of Beef Cattle Population}

Beef cattle in Banyumas are equitably widespread across the sub-districts. It shows that beef cattle did not require specific conditions to develop and could grow with scant feed. Beef cattle population in the past six years is presented in Table 1.

Table 1. Beef cattle population in sub-districts in Banyumas

\begin{tabular}{|c|c|c|c|c|c|c|c|}
\hline \multirow[t]{2}{*}{ No } & \multirow[t]{2}{*}{ Sub-District } & \multicolumn{6}{|c|}{ Year } \\
\hline & & 2013 & 2014 & 2015 & 2016 & 2017 & 2018 \\
\hline 01 & Lumbir & 189 & 393 & 301 & 340 & 403 & 390 \\
\hline 02 & Wangon & 384 & 317 & 516 & 465 & 532 & 552 \\
\hline 03 & Jatilawang & 599 & 496 & 612 & 585 & 478 & 458 \\
\hline 04 & Rawalo & 347 & 161 & 176 & 158 & 158 & 145 \\
\hline 05 & Kebasen & 385 & 190 & 244 & 208 & 306 & 265 \\
\hline 06 & Kemranjen & 274 & 207 & 302 & 302 & 249 & 236 \\
\hline 07 & Sumpiuh & 200 & 163 & 138 & 94 & 122 & 143 \\
\hline 08 & Tambak & 212 & 34 & 106 & 106 & 201 & 190 \\
\hline 09 & Somagede & 521 & 154 & 242 & 242 & 643 & 791 \\
\hline 10 & Kalibagor & 1,772 & 1,010 & 892 & 892 & 1,642 & 2,154 \\
\hline 11 & Banyumas & 359 & 329 & 332 & 322 & 322 & 394 \\
\hline 12 & Patikraja & 497 & 59 & 185 & 229 & 229 & 306 \\
\hline 13 & Purwojati & 514 & 603 & 553 & 577 & 355 & 234 \\
\hline 14 & Ajibarang & 730 & 646 & 789 & 789 & 789 & 413 \\
\hline 15 & Gumelar & 302 & 67 & 60 & 60 & 137 & 224 \\
\hline 16 & Pekuncen & 357 & 223 & 154 & 154 & 216 & 244 \\
\hline 17 & Cilongok & 889 & 576 & 523 & 596 & 520 & 508 \\
\hline 18 & Karanglewas & 390 & 267 & 260 & 263 & 77 & 224 \\
\hline 19 & Kedungbanteng & 696 & 401 & 508 & 502 & 477 & 562 \\
\hline 20 & Baturaden & 536 & 452 & 617 & 582 & 603 & 582 \\
\hline 21 & Sumbang & 1,756 & 2,043 & 2519 & 2,500 & 2,658 & 2,500 \\
\hline 22 & Kembaran & 176 & 2,119 & 1984 & 1,828 & 2,012 & 1,906 \\
\hline 23 & Sokaraja & 909 & 1,129 & 1030 & 1,030 & 1,022 & 697 \\
\hline 24 & Purwokerto Selatan & 49 & 124 & 143 & 143 & 121 & 129 \\
\hline 25 & Purwokerto Barat & 23 & 23 & 19 & 23 & 23 & 23 \\
\hline 26 & Purwokerto Timur & 40 & 79 & 52 & 45 & 45 & 59 \\
\hline \multirow[t]{2}{*}{27} & Purwokerto Utara & 155 & 62 & 59 & 21 & 21 & 21 \\
\hline & Kab. Banyumas & 13,261 & 12,327 & 13,316 & 13,056 & 14,361 & 14,350 \\
\hline
\end{tabular}

Source: Simda Ekonomi Hijau Banyumas 2019, processed data

Table 1 shows that beef cattle are spread across sub-districts in Banyumas. Some districts have more than 1000 cattle, i.e. Sumbang, Kalibagor and Kembaran.
Data in Table 1 was analysed using a simple regression method connecting year-I with the population per year. The result of trend analysis on beef cattle population is presented in Figure 1. 


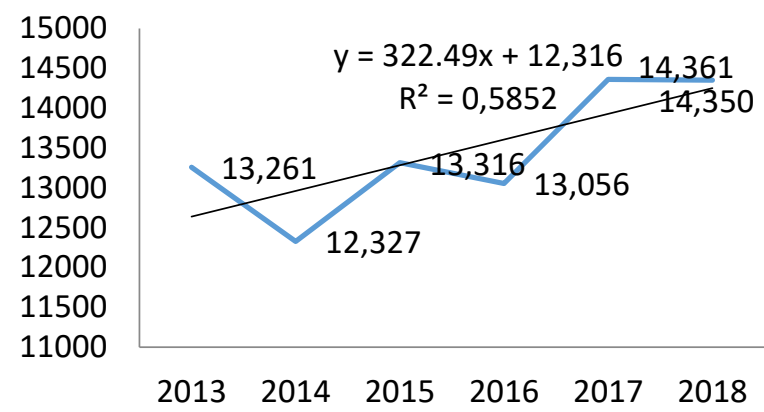

Figure 1. Trend of Beef cattle population Banyumas

The analysis result showed that the population trend significantly increases during six years despite the fluctuation. The lowest population was observed in 2014 (12,327), the highest was 2017 (14,361), and the past year 2018 saw a slight decrease. A positive trend shows that beef cattle in Banyumas is of potential optimum development when focusing on the basic area.

Figure 1 indicates that trend beef cattle population Banyumas tend to increase (positive) with a regression equation as follow:

$$
Y=12,316+322.49 X \text {, }
$$

Coefficient determination $\left(R^{2}\right)=0.5852$

According to Roessali et al. (2005), beef cattle breeding for commercial meat production is still low. Furthermore, the eastern part of Indonesia contributes $16 \%$ of the national beef cattle population with a large pasture field. However, the cattle lose weight during the dry season, accompanied by a high mortality rate and low birth rate. Other barriers include the decreased pasturing area, low-quality resources, difficult access to loan agencies, and low technology adoption (Syamsu et al. 2003). The driving factors of beef cattle development are the increasing market demand of beef, human resource availability, the government policy for developing beef cattle, high availability of forage and agricultural waste, and the resilient beef cattle business against the global economic crisis (Kariyasa 2005; Gordeyase et al. 2006; Utomo 2004).

\section{Potential Beef Cattle in Banyumas}

Location Quotient (LQ) method is an approach to analyze prime commodities. LQ is feasible for analyzing the potential or basic sectors in an area. According to Rustiadi et al. (2011), a basic area is a determining factor to economic development - a regional commodity system is expected to improve the efficient commodity production and distribution that eventually maximize the comparative prime of each area. In this study, LQ analysis was utilized to observe the basic sector of beef cattle breeding per sub-district in Banyumas. The result of LQ analysis in Banyumas is presented in Table 2.

Table 2. The potential basic sector based on LQ value of beef cattle population in Banyumas

\begin{tabular}{lcc}
\hline \multicolumn{1}{c}{ Sub-district } & LQ & Ranking \\
\hline Kembaran & 3.35 & 1 \\
Sokaraja & 2.81 & 2 \\
Kalibagor & 2.75 & 3 \\
Kedungbantg & 2.50 & 4 \\
Purwokerto Timur & 2.49 & 5 \\
Karanglewas & 2.35 & 6 \\
Purwokerto Selatan & 2.24 & 7 \\
Sumbang & 2.15 & 8 \\
Baturaden & 1.44 & 9 \\
\hline
\end{tabular}

Table 2 shows that some sub-districts are potential for beef cattle development centres in Banyumas with LQ>1 namely (highest to lowest score) Kembaran, Sokaraja, Kalibagor, Kedungbanteng, East Purwokerto, Karanglewas, South Purwokerto, Sumbang and Baturraden. Sub-districts located in ex-city Purwokerto were excluded because of the township nature in a developing agricultural area. Mukson et al. (2014) reported that Banyumas is not a central 
beef cattle development; however, due to negative carrying capacity, some area in Banyumas is potential for developing beef cattle.

\section{Strategy of Beef Cattle Development in Banyumas}

The strategy to develop beef cattle is formulated using a SWOT matrix. Purnomo et al. (2017) stated that the SWOT matrix illustrates the internal factors in developing the beef cattle industry combined with external factors to formulate an alternative strategy for a business venture. Additionally, Santosa et al. (2013) stated that developing dairy cattle also applied the SWOT matrix. The result of SWOT matrix analysis to develop beef cattle in Banyumas is presented in IFAS (Internal Factors Analysis Summary) and EFAS (External Factors Analysis Summary) in Table 3 and 4.

Strength as the important component includes the abundant agricultural waste that had not been utilized optimally for feed (1.0) and the close proximity from breeders to animal markets (0.75). The total score of two strengths was 3.2. According to Susanti et al (2014) that Banyumas Regency has excess availability of forage feed.

The most significant weakness factor is the traditional breeding management $(0.8421)$ and the low cattle size (0.8421). Total weakness score was 3.1905. The overall internal factors (S $-\mathrm{W}$ ) was 0.0298 .

The most significant opportunity factor was the increasing meat demand along with the growing population, society income and awareness on nutrition demand, scoring 0.9412 . The other opportunity factor was the available regional animal factor as an effective marketing space for beef cattle (0.7059). The total opportunity score was 2.8235 .
Table 3. IFAS (Internal Factors Analysis Summary) of beef cattle in Banyumas

\begin{tabular}{llccc}
\hline No & Internal factors & Weight & Rating & Score \\
\hline A & STRENGTH & & & \\
1 & $\begin{array}{l}\text { Abundant agricultural } \\
\text { waste for feed }\end{array}$ & 0.2500 & 4 & 1.0000 \\
2 & $\begin{array}{l}\text { Adequate breeding } \\
\text { experience } \\
3\end{array}$ & 0.1875 & 3 & 0.5625 \\
4 & $\begin{array}{l}\text { Pasteur availability } \\
\text { Many }\end{array}$ & 0.1875 & 3 & 0.5625 \\
5 & $\begin{array}{l}\text { farmers/breeders } \\
\text { Close proximity to } \\
\text { animal market }\end{array}$ & 0.1250 & 3 & 0.3750 \\
\hline & Total & 1.0000 & 3 & 0.7500 \\
\hline & & & & 3.2500 \\
\hline
\end{tabular}

\begin{tabular}{|c|c|c|c|c|}
\hline No & Internal factors & Weight & Rating & Score \\
\hline A & WEAKNESS & & & \\
\hline 1 & $\begin{array}{l}\text { Traditional } \\
\text { maintenance }\end{array}$ & 0.2105 & 4 & 0.8421 \\
\hline 2 & $\begin{array}{l}\text { Low knowledge } \\
\text { on feed }\end{array}$ & 0.1579 & 3 & 0.4737 \\
\hline 3 & $\begin{array}{l}\text { Breeders' low } \\
\text { education level }\end{array}$ & 0.1579 & 3 & 0.4737 \\
\hline 4 & Low cattle size & 0.2105 & 4 & 0.8421 \\
\hline 5 & $\begin{array}{l}\text { Unutilized } \\
\text { waste }\end{array}$ & 0.1053 & 2 & 0.2105 \\
\hline 6 & Limited capital & 0.1579 & 3 & 0.4737 \\
\hline 7 & $\begin{array}{l}\text { Breeding as a } \\
\text { casual job }\end{array}$ & 0.0952 & 2 & 0.1905 \\
\hline & Total & 1.0000 & & 31.9050 \\
\hline
\end{tabular}

The biggest threat to the development of beef cattle in Banyumas was the substitute products for beef (poultry, mutton, lamb, buffalo) with a lower price that attracts consumers. The score for this threat factor was 0.7059 . The other threat with a similar score (0.7059) was the displaced beef cattle breeding due to the functional shift of agricultural land. Total threat score was 3.1176. The overall external factors (O - T) obtained a negative score, i.e. -0.2941 . The result of SWOT analysis showed that the current beef cattle breeding was at quadrant II (0.0298; - 0.2941), as illustrated in Figure 2. 
Table 4. EFAS (External Factors Analysis Summary) of Beef Cattle in Banyumas

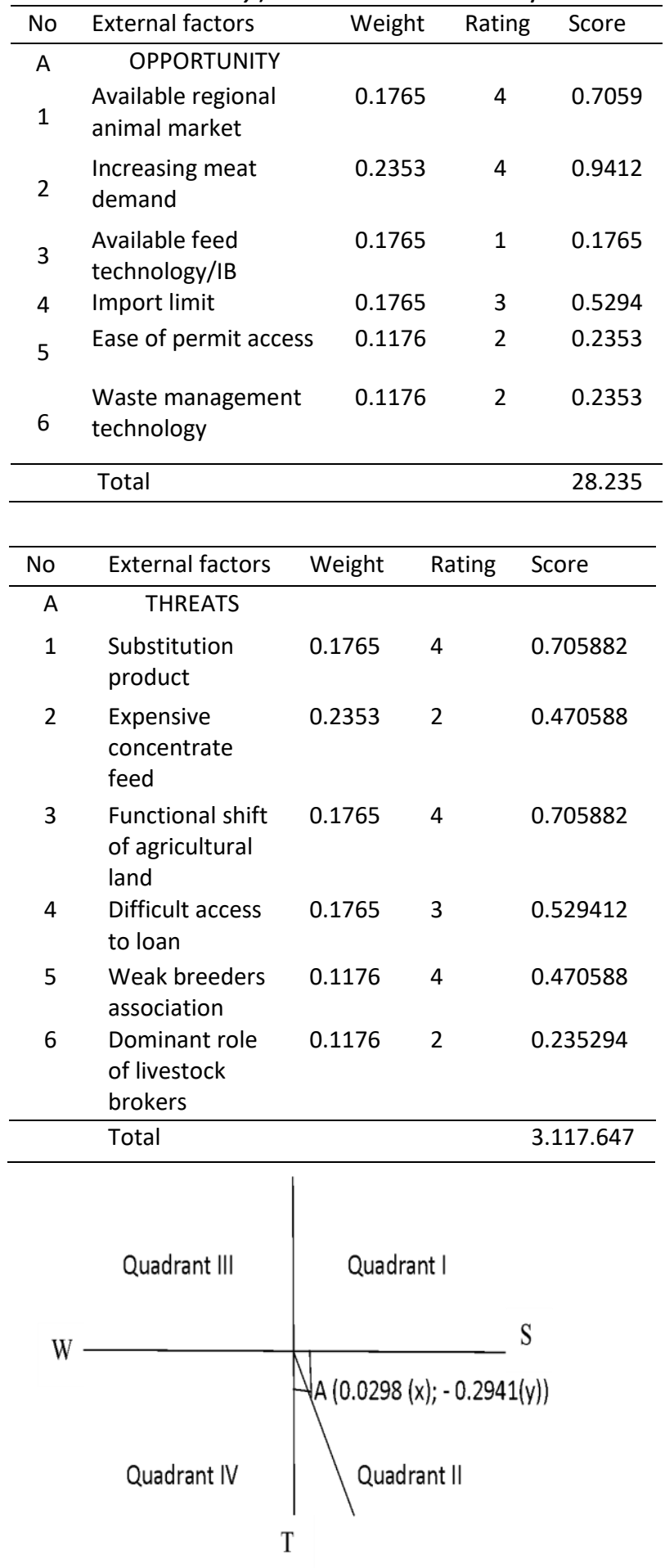

Figure 2. SWOT analysis result of Beef Cattle in Banyumas
The analysis result showed that the current beef cattle breeding in Banyumas was in quadrant II. Therefore, the appropriate strategy to develop beef cattle was S-T (Strength Threats) utilized internal factors to avoid the influence of external factors (Kurniawan et al. 2013). The strategy to develop beef cattle in Banyumas was a differential strategy to improve cattle productivity through optimization of agricultural waste, improving comparative prime, and breeding in a more suitable area. This finding was in line with Arelovich et al. (2011); Huyen et al. (2012); Mayulu et al. (2010) and Priyanto (2011) that beef cattle development required area grouping according to forage availability.

Some strategies to develop dairy cattle in Banyumas included:

1. Improving the utilization of agricultural waste for fresh or preserved cattle feed.

2. Utilizing idle land for forage fields.

3. Optimizing comparative prime in terms of an area close to the animal market.

4. Training breeders on composing cheap, quality feed.

5. Positioning the breeding location in a communal cage according to the objectives.

\section{Conclusions}

The potential sub-districts to develop beef cattle in Banyumas included Kembaran, Sokaraja, Kalibagor, Kedung banteng, Karanglewas, Sumbang and Baturraden. The key strategy to develop beef cattle in Banyumas was the differential strategy.

Developing the beef cattle industry in Banyumas was feasible through optimization of agricultural waste and comparative prime and improving breeders' knowledge and skill in composing quality feed. Breeding in suitable locations is also advised. 


\section{Acknowledgement}

The authors express sincerest gratitude to Universitas Jenderal Soedirman and the Ministry of Research, Technology and Higher Education for the funding through Competence Reinforcement Research grant 2019.

\section{References}

Arelovich, HM, RD Bravo and MF Martinez. 2011. Development, Characteristics, and Trends for Beef Cattle Production in Argentina. Animal Frontiers. The Review Magazine of Animal Agriculture. Doi: 10,2527/af.2011-0021 Animal Frontiers 2011. 1(2): 37-45.

Fahmi, I. 2011. Manajemen Teori, Aplikasi and Kasus. Bandung. Alfabeta.

Gordeyase, IKM, R Hartanto and WD Pratiwi. 2006. Proyeksi daya dukung pakan limbah tanaman pangan untuk ternak ruminansia di Jawa Tengah. J. Indon. Trop. Anim. Agric. 32(4): 285-292.

Hartono, B. 2012. Peran Daya Dukung Wilatah Terhadap Pengembangan Usaha Peternakan Sapi Madura. Jurnal Ekonomi Pembangunan 13(2): 216-326.

Hendarto, RM. 2000. Analisis Potensi Daerah dalam Pembangunan Ekonomi. Makalah Diklat. Fakultas Ekonomi Universitas Diponegoro, Semarang.

Huyen, LTT, DTV Tuyet, A Markemann, P Herold and AV Zarat. 2012. Beef Cattle Keeping by Smallholders in A Mountainnous Province of Northern Vietnam in Relation to Proverty Status, Community Remoteness and Ethnicity. Journal Animal Production Science. 53(2): 163-172. Doi.org/10.1071/AN12117.

Kariyasa, K. 2005. Sistem integrasi tanamanternakdalam perspektif reorientasi kebijakan subsidi pupuk and peningkatan pendapatan petani. Jurnal Analisis Kebijakan Pertanian. 3(1): 68-80.

Kurniawan, MFT, DP Darmawan and NWS Astuti. 2013. Strategi Pengembangan Agribisnis
Peternakan Ayam Petelur di Kabupaten Tabanan. Jurnal Manajemen Agribisns. 1(2).

Mayulu, H, Sunarso, Cl Sutrisno and Sumarsono. 2010. Kebijaksananaa Pengembangan Sapi Potong di Indonesia. Jurnal Litbang Pertanian. 29 (1): 3441.

Mukson, W Roessali and H Setiyawan. 2014. Analisis Pengembangan Sapi Potong dalam Mendukung Swasembada Daging di Jawa Tengah. Jurnal Peternakan Indonesia. 16(1).

Priyanto, P. 2011. Strategi Pengembangan Usaha Beef cattle Dalam Mendukung Program Swasembada Daging Sapi Dan Kerbau Tahun 2014. Jurnal Litbang Pertanian. 30(3): $108-116$.

Purnomo, SH, ET Rahayu and SB Antoro, 2017. Strategi Pengembangan Peternakan Sapi Potong Rakyat di Sub-district Wiryantoro Kabupaten Wonogiri. Buletin Peternakan 41(4): 484-494.

Roessali, W, BT Eddy and A Murthado. 2005. Upaya pengembangan usaha sapi potong melalui entinitas agribisnis "corporate farming"di Kabupaten Grobogan. Jurnal Sosial Ekonomi Peternakan. 1(1): 25-30.

Rustiadi, E, S Saefulhakim and DR Panuju. 2011. Perencanaan and Pengembangan Wilayah. Jakarta (ID): Crestpent Press and Yayasan Pusta Obor Indonesia.

Santosa, SI, A Setiadi and R Wulandari. 2013. Analisis Potensi Pengembangan Usaha Peternakan Sapi Perah Dengan Menggunakan Paradigma Agribisnis Di Sub-district Musuk Kabupaten Boyolali. Buletin Peternakan 37(2): 125-135.

Susanti, Y, DS Priyarsono and S Mulatsih. 2014. Pengembangan Peternakan Sapi Potong untuk Peningkatan Perekonomian Provinsi Jawa Tengah; Suatu Pendekatan Perencanaan Wilayah. Jurnal Agribisnis Indonesia. 2(2): 177-190.

Syamsu, AJ, LA Sofyan, K Mudikdjo and G Said. 2003. Daya dukung limbah pertanian sebagai sumber pakan ternak ruminansia di Indonesia. Wartazoa. 13(1): 30-37.

Utomo, BN and E Widjaja. 2004. Limbah padat pengolahan sawit sebagai sumber nutrisi ternak ruminansia. Jurnal Penelitian and Pengembangan Pertanian 23(1): 21-28. 